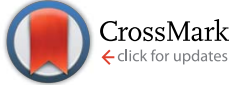

Cite this: RSC Adv., 2014, 4, 49115

Received 25th July 2014

Accepted 24th September 2014

DOI: $10.1039 / c 4 r a 07625 g$

www.rsc.org/advances

\section{Low ionic liquid concentration in water: a green and simple approach to improve activity and selectivity of lipases}

\author{
Marco Filice, ${ }^{a}$ Oscar Romero, $\dagger^{\mathrm{a}}$ Olga Abian, ${ }^{\text {bcd }}$ Blanca de las Rivas ${ }^{\mathrm{e}}$ \\ and Jose M. Palomo*a
}

The activity of several commercial and genetically engineered lipases, already immobilized on octyl-Sepharose, in aqueous solutions containing ionic liquids (ILs) in a molar concentration of $0.01 \mathrm{~mol} \mathrm{~L}^{-1}$ was investigated. Strong variations in the hydrolytic activity values were found depending on the lipase, the ionic liquid and the substrate used. The most interesting results were found in the engineered variants of Geobacillus thermocatenolatus lipase (GTL). The activity of GTL $\sigma-L 230 C$ variant in the monodeacetylation of peracetylated glucal increased seven fold when using 1-ethyl-3-methylimidazoliumhexafluorophosphate [emim $\left[\mathrm{PF}_{6}\right]$ and fivefold when using 1-ethyl-3-methylimidazolium methyl sulphate [emim] $\left[\mathrm{MeSO}_{3}\right]$. In general, ILs containing $\mathrm{BF}_{4}{ }^{-}$had a very negative effect on the enzyme activity. Moreover, improvements in the enantio and regioselectivity of the immobilized lipases were obtained by adding ILs to the reaction medium. The regioselectivity of Candida rugosa lipase in the hydrolysis of peracetylated thymidine improved (from $72 \%$ to $81 \%$ yield of $\mathrm{C}-5$ monodeprotected product) in the presence of [emim] [PF 6 ]. More interestingly, the addition of 1-butyl-2,3-dimethylimidazolium hexafluorophosphate [bdmim][PF6] improved the regioselectivity of immobilized GTL $\sigma$-L230C variant in the hydrolysis of peracetylated glucal, from $78 \%$ to $96 \%$ yield of the C-3 monodeprotected product. Circular dichroism and fluorescence experiments revealed conformational changes in the tertiary structure of the enzyme induced by the ionic liquid which could explain these phenomena.

\section{Introduction}

Lipases, acylglycerol hydrolases (EC:3.1.1.3), are one of the most used enzymes in biotransformations. ${ }^{1-5}$ The catalytic mechanism of a lipase is based on the movement of an oligopeptide chain "lid" in its structure. In homogeneous aqueous media the lipase exists mainly in a closed conformation, where the lid maintains the enzyme active site secluded from the medium. ${ }^{6}$ However in the presence of hydrophobic interfaces, this peptide has a tendency to shift generating an open conformation of the lipase, which exposes a large number of hydrophobic residues to the medium for the adsorption on this interface. ${ }^{6}$ This

${ }^{a}$ Departamento de Biocatálisis, Instituto de Catálisis (CSIC), Marie Curie 2. Cantoblanco. Campus UAM, 28049 Madrid, Spain. E-mail: josempalomo@icp.csic.es; Fax: +34915854760

${ }^{b} I I S$ Aragón, Instituto Aragonés de Ciencias de la Salud (IACS), Zaragoza, Spain ${ }^{c}$ Institute of Biocomputation and Physics of Complex Systems (BIFI), Joint Unit IQFRCSIC-BIFI, Universidad de Zaragoza, Zaragoza, Spain

${ }^{d}$ Centro de Investigación Biomédica en Red en el Área Temática de Enfermedades Hepáticas y Digestivas (CIBERehd), Spain

${ }^{e}$ Laboratorio de Biotecnología Microbiana, Instituto de Ciencia y Tecnología de alimentos y Nutrición, (ICTAN-CSIC), Madrid, Spain

$\dagger$ Present address: Institute of Biomaterial Science, Helmholtz Zentrum Geesthacht, Teltow, Germany. process is more complex and normally exists an equilibrium between these two lipase conformations which depends on the medium conditions to be shifted mainly to the closed or the open form. ${ }^{7}$

Based on that, this equilibrium has successfully modified by different strategies. Immobilization protocols to rigidify or fix a particular conformation has been successfully used to improve the activity and specially the enantio and regioselectivity of these enzymes. ${ }^{\mathbf{8}-10}$ Other methodologies such as chemical modification of the enzyme surface ${ }^{\mathbf{1 1 , 1 2}}$ or changes in experimental parameters ( $\mathrm{pH}, \mathrm{T}$ or the addition of co-solvents) have been quite useful to alter the lipase catalysis. ${ }^{\mathbf{8 , 1 3}}$

In this sense, ionic liquids (ILs) have emerged as a very attractive alternative to environmentally harmful organic solvents. ${ }^{14}$

In particular, the large number of applications of ILs with lipases has been published, ${ }^{\mathbf{1 5 - 1 8}}$ however the use of full or even higher concentration of ILs may decrease, or also completely inactivates the enzymes, since they have the capacity to interact with the water molecules around the enzyme surface ${ }^{19}$ and in some cases, with the enzyme itself $^{20}$ making difficult a real application of them. In this context, there is a strong and urgent need to increase the catalytic properties of lipases in ILs. 


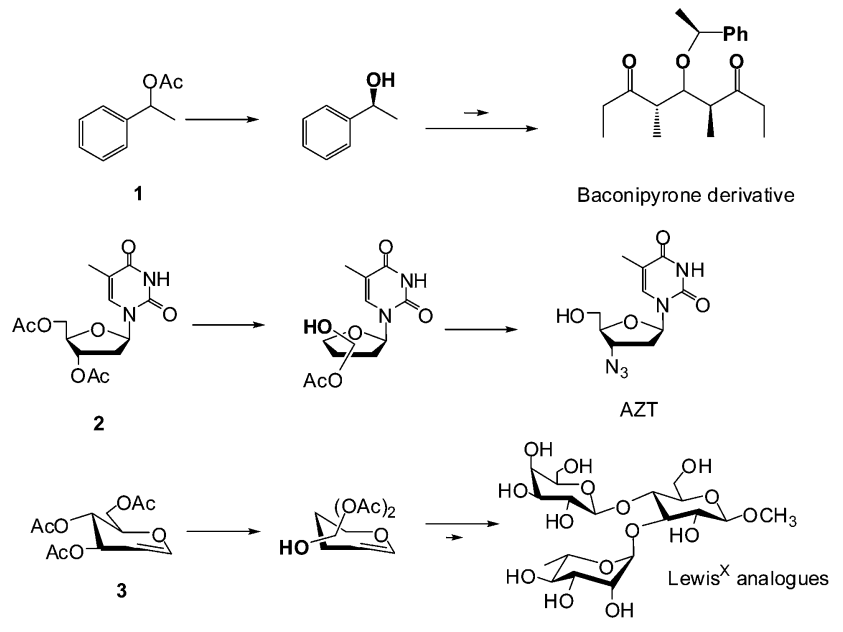

Scheme 1 Green biocatalytic preparation of monodeacetylated drug intermediates.

Recently, the use of microemulsion of ILs in water enhanced the lipase activity based on the interfacial activation mechanism. ${ }^{21}$ In a preliminary work in the development of an efficient synthesis of a carbohydrate derivative we observed that the addition of small amounts of ILs in the reaction media considerably improved the enzyme activity of $R$. miehei lipase, though any improvement of regioselectivity was not achieved in this case. ${ }^{22}$

Herein we have demonstrated that the application of micromolar concentration of ILs in aqueous solution can alter the activity and for the first time the enantio and regioselectivity of lipases. This method improves lipase catalysis without requiring any pretreatment of the enzyme or manipulation or modification of the ILs.

In order to establish a general application, this method was evaluated using three of the most used commercial lipases, from Pseudomonas fluorescens (PFL), from Candida antarctica $\mathrm{B}$ (CAL-B) and from Candida rugosa (CRL). Furthermore four engineered mutants of Geobacillus thermocatenulatus lipase (GTL), a more complex enzyme constituted by two different lids and very hydrophobic pocket, were used. In all cases the lipases were immobilized on the hydrophobic commercial matrix octylSepharose, fixing their open conformation. For the evaluation of lipase properties, a deacetylation process, a quite useful biotransformation in organic synthesis, was selected. Three different acetylated compounds, $( \pm)$-O-acetyl-1-phenylethanol (1), 3,5-di-O-acetyl-thymidine (2) and 3,4,6-tri- $O$-acetyl-glucal (3), were used as model substrates to evaluate the enantio and regioselectivity of the lipases on these new conditions, creating interesting selective monodeacetylated products, useful building blocks in the synthesis of more complex pharmaceutical molecules (Scheme 1). ${ }^{23,24}$

\section{Results and discussion}

The catalytic activity of a set of seven different pure and immobilized lipases, three commercial (PFL, CRL, CAL-B) and four
Table 1 Specific activity of commercial lipases immobilized on octylSepharose in the hydrolysis of 1 in the presence of different $\mathrm{ILs}^{a}$

\begin{tabular}{lccc}
\hline ILs & PFL & CAL-B & CRL \\
\hline- & 31.30 & 592 & 8.44 \\
{$[\mathrm{emim}]\left[\mathrm{BF}_{4}\right]$} & 55.78 & 258 & - \\
{$[\mathrm{emim}]\left[\mathrm{PF}_{6}\right]$} & 95.61 & 748 & 13.76 \\
{$[\mathrm{emim}]\left[\mathrm{NO}_{3}\right]$} & 85.71 & 555 & 14.85 \\
{$[\mathrm{emim}]\left[\mathrm{MeOSO}_{3}\right]$} & 91.21 & 726 & 12.33 \\
{$[\mathrm{bmim}]\left[\mathrm{BF}_{4}\right]$} & 71.72 & 449 & - \\
{$[\mathrm{bdmim}]\left[\mathrm{BF}_{4}\right]$} & 74.01 & 882 & - \\
{$[\mathrm{bdmim}]\left[\mathrm{PF}_{6}\right]$} & 64.96 & 936 & 15.21
\end{tabular}

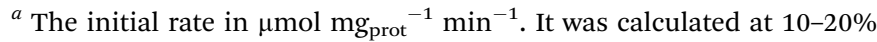
yield. IL without enzyme was tested and no conversion was detected. The experiments were performed by triplicate and error was less than $5 \%$.

genetically engineered mutants from GTL [GTL-C65S/C296S (GTL $\sigma$ ), BTL-C65S/C296S/A193C (GTL $\sigma-A 193 C)$, GTL-C65S/

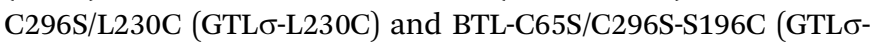
S196C)] was evaluated in the presence of seven different ionic liquids: 1-ethyl-3-methylimidazolium tetrafluoroborate [emim] $\left[\mathrm{BF}_{4}\right]$, 1-ethyl-3-methylimidazoliumhexafluorophosphate [emim] $\left[\mathrm{PF}_{6}\right]$, 1-ethyl-3-methylimidazolium nitrate [emim $]\left[\mathrm{NO}_{3}\right]$, 1-ethyl3-methylimidazolium methyl sulphate $[\mathrm{emim}]\left[\mathrm{MeOSO}_{3}\right]$, 1butyl-3-methylimidazolium tetrafluoroborate $[\mathrm{bmim}]\left[\mathrm{BF}_{4}\right]$, 1butyl-2,3-dimethylimidazolium tetrafluoroborate $[\mathrm{bdmim}]\left[\mathrm{BF}_{4}\right]$ and 1-butyl-2,3-dimethylimidazolium hexafluorophosphate [bdmim $]\left[\mathrm{PF}_{6}\right]$ as ionic liquid molar concentration of $0.01 \mathrm{~mol} \mathrm{~L}^{-1}$ in aqueous media at $\mathrm{pH} 5$.

The addition of ILs was positive for the PFL activity in the hydrolysis of 1 . A 3 fold increase of the activity was found in the presence of $[\mathrm{emim}]\left[\mathrm{PF}_{6}\right]$ and $[\mathrm{emim}]\left[\mathrm{MeOSO}_{3}\right]$ (Table 1). However, with 2 and 3 positive results were only found with ILs containing $\mathrm{PF}_{6}{ }^{-}, \mathrm{NO}_{3}{ }^{-}$or $\mathrm{MeOSO}_{3}{ }^{-}$ions, whereas a high decrease in the enzyme activity was observed using $\mathrm{BF}_{4}$-based ILs (Tables 2 and 3).

The profile was quite similar for CAL-B. Moreover the use of [bdmim] $\left[\mathrm{PF}_{6}\right]$, a more hydrophobic IL, showed a good increase of the enzyme activity in the hydrolysis of $\mathbf{1}$ and $\mathbf{3}$ (Tables 1 and $3)$. In the case of CRL, the effect of $\mathrm{BF}_{4}{ }^{-}$was even more negative

Table 2 Specific activity of commercial lipases immobilized on octylSepharose in the hydrolysis of 2 in the presence of different ILs ${ }^{a}$

\begin{tabular}{lccc}
\hline ILs & PFL & CAL-B & CRL \\
\hline- & 19.40 & 28.1 & 10.5 \\
{$[\mathrm{emim}]\left[\mathrm{BF}_{4}\right]$} & 17.70 & 9.3 & - \\
{$[\mathrm{emim}]\left[\mathrm{PF}_{6}\right]$} & 19.40 & 29.6 & 11 \\
{$[\mathrm{emim}]\left[\mathrm{NO}_{3}\right]$} & 17.43 & 28.1 & 8.5 \\
{$[\mathrm{emim}]\left[\mathrm{MeOSO}_{3}\right]$} & 18.93 & 29.6 & 17.5 \\
{$[\mathrm{bmim}]\left[\mathrm{BF}_{4}\right]$} & 14.68 & 9.3 & - \\
{$[\mathrm{bdmim}]\left[\mathrm{BF}_{4}\right]$} & 18.43 & 10.4 & - \\
{$[\mathrm{bdmim}]\left[\mathrm{PF}_{6}\right]$} & 18.75 & 15.6 & 8.46
\end{tabular}

${ }^{a}$ The initial rate in $\mu \mathrm{mol} \mathrm{mg} \mathrm{prot}^{-1} \mathrm{~h}^{-1} \times 10^{-1}$. It was calculated at $10-$ $20 \%$ yield. IL without enzyme was tested and no conversion was detected. The experiments were performed by triplicate and error was less than $5 \%$. 
Table 3 Specific activity of commercial lipases immobilized on octylSepharose in the hydrolysis of 3 in the presence of different ILs ${ }^{a}$

\begin{tabular}{lccr}
\hline ILs & PFL & CAL-B & CRL \\
\hline- & 10.5 & 4.88 & 17.10 \\
{$[\mathrm{emim}]\left[\mathrm{BF}_{4}\right]$} & 1.44 & 0.30 & 1.20 \\
{$[\mathrm{emim}]\left[\mathrm{PF}_{6}\right]$} & 12 & 7.95 & 12.30 \\
{$[\mathrm{emim}]\left[\mathrm{NO}_{3}\right]$} & 11.4 & 8.45 & 10.80 \\
{$[\mathrm{emim}]\left[\mathrm{MeOSO}_{3}\right]$} & 9.6 & 8.10 & 15.10 \\
{$[\mathrm{bmim}]\left[\mathrm{BF}_{4}\right]$} & 0.9 & 0.30 & 0.60 \\
{$[\mathrm{bdmim}]\left[\mathrm{BF}_{4}\right]$} & 1.20 & 0.33 & 0.60 \\
{$[\mathrm{bdmim}]\left[\mathrm{PF}_{6}\right]$} & 10.95 & 7.95 & 8.85
\end{tabular}

${ }^{a}$ The initial rate in $\mu \mathrm{mol} \mathrm{mg} \mathrm{prot}^{-1} \mathrm{~h}^{-1}$. It was calculated at $10-20 \%$ yield. IL without enzyme was tested and no conversion was detected. The experiments were performed by triplicate and error was less than $5 \%$.

Table 4 Specific activities of immobilized GTL variants on the regioselective hydrolysis of 3 by in the presence of different $\mathrm{ILs}^{a}$

\begin{tabular}{|c|c|c|c|c|}
\hline ILs & GTL $\sigma$ & GTL $\sigma-A 193 C$ & GTL $\sigma-S 196 C$ & GTL $\sigma-L 230 \mathrm{C}$ \\
\hline - & 5.1 & 15.7 & 8.0 & 10.8 \\
\hline$[\mathrm{emim}]\left[\mathrm{BF}_{4}\right]$ & 6.9 & 34.9 & 21.6 & 50.1 \\
\hline$[\mathrm{emim}]\left[\mathrm{PF}_{6}\right]$ & 6.6 & 32.1 & 21.8 & 70.6 \\
\hline$[\mathrm{emim}]\left[\mathrm{NO}_{3}\right]$ & 8.6 & 17.4 & 12.2 & 27.3 \\
\hline$[\mathrm{emim}]\left[\mathrm{MeOSO}_{3}\right]$ & 6.1 & 28.4 & 15.6 & 53.8 \\
\hline$[\mathrm{bmim}]\left[\mathrm{BF}_{4}\right]$ & 6.4 & 25.9 & 10.2 & 21.3 \\
\hline$[\mathrm{bdmim}]\left[\mathrm{BF}_{4}\right]$ & 8.5 & 20.1 & 12.4 & 9.2 \\
\hline$[\mathrm{bdmim}]\left[\mathrm{PF}_{6}\right]$ & 3.6 & 10.0 & 5.4 & 23.8 \\
\hline
\end{tabular}

${ }^{a}$ The initial rate is expressed in $\mu \mathrm{mol} \mathrm{mg}_{\text {prot }}{ }^{-1} \mathrm{~min}^{-1} \times 10^{-3}$. It was calculated at $10-20 \%$ yield. IL without enzyme was tested and no conversion was detected. The experiments were performed by triplicate and error was less than $5 \%$.

to the enzyme and no activity in the presence of ILs containing this anion was found for this enzyme in the hydrolysis of $\mathbf{1}$ and $\mathbf{2}$ (Tables 1 and 2). In general, the addition of ILs such as [emim] $\left[\mathrm{MeOSO}_{3}\right]$ or $[\mathrm{emim}]\left[\mathrm{PF}_{6}\right]$ was the most positive for these enzyme activity.

Other ILs concentrations such as $0.02,0.03$ or $0.04 \mathrm{~mol} \mathrm{~L}^{-1}$ were tested with no differences in results (data not shown).

More interesting variations in the enzyme activity with the addition of ILs were obtained for four different GTL variants in the hydrolysis of 3 (Table 4). Interestingly, the effect of ILs was significantly higher in the GTL $\sigma$ variants with a unique cysteine in the lipase lid site in different positions (GTL $\sigma$-A193C, GTL $\sigma$ S196C and GTL $\sigma$-L230C). The enzymatic activity of GTL $\sigma$-L230C increased in the presence of almost all ILs tested, in particular 7 fold in the presence of [emim] $\left[\mathrm{PF}_{6}\right]$ and 5 fold with [emim] $\left[\mathrm{MeOSO}_{3}\right]$. These activity improvements are the highest one described in the literature for this enzyme in this reaction. ${ }^{25}$ [emim] $\left[\mathrm{PF}_{6}\right]$ improved the activity of the other variants, up to 3 fold for GTL $\sigma$-S196C and 2 fold for GTL $\sigma$-A193C.

The presence of ILs containing $\mathrm{BF}_{4}{ }^{-}$in the GTL catalysis did not cause the negative effect observed for the other lipases and, for example, $[\mathrm{emim}]\left[\mathrm{BF}_{4}\right]$ enhanced the activity for all variants from 3 to 5 fold (Table 4).

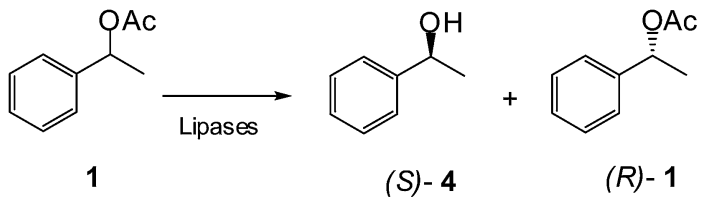

Scheme 2 Enzymatic kinetic resolution of 1.

Table 5 Enantioselectivity of immobilized lipases catalyzing hydrolysis of $( \pm)$-1 catalyzed in the presence of different ILS

\begin{tabular}{llll}
\hline & \multicolumn{4}{c}{$E$ value $^{a}(\mathrm{ee}, \%)$} & \\
\cline { 2 - 4 } $\mathrm{ILs}$ & $\mathrm{PFL}$ & $\mathrm{CALB}$ & $\mathrm{CRL}$ \\
\hline- & $>100(>99)$ & $>100(>99)$ & $14(87)$ \\
{$[\mathrm{emim}]\left[\mathrm{BF}_{4}\right]$} & $>100(>99)$ & $>100(>99)$ & - \\
{$[\mathrm{emim}]\left[\mathrm{PF}_{6}\right]$} & $>100(>99)$ & $>100(>99)$ & $22(91)$ \\
{$[\mathrm{emim}]\left[\mathrm{NO}_{3}\right]$} & $>100(>99)$ & $>100(>99)$ & $19(90)$ \\
{$[\mathrm{emim}]\left[\mathrm{MeOSO}_{3}\right]$} & $>100(>99)$ & $>100(>99)$ & $19(90)$ \\
{$[\mathrm{bmim}]\left[\mathrm{BF}_{4}\right]$} & $>100(>99)$ & $>100(>99)$ & - \\
{$[\mathrm{bdmim}]\left[\mathrm{BF}_{4}\right]$} & $>100(>99)$ & $>100(>99)$ & - \\
{$[\mathrm{bdmim}]\left[\mathrm{PF}_{6}\right]$} & $>100(>99)$ & $>100(>99)$ & $18(89)$ \\
$a$ ee of product calculated at 15\% conversion. &
\end{tabular}

Additionally, the lipase selectivity was improved because of the presence of ILs. For CAL-B and PFL, the enantioselectivity in the kinetic resolution of $\mathbf{1}$ (Scheme 2) was excellent (ee $>99 \%$, $E$ value $>100$ ) and it was conserved in the presence of all ILs. In the case of CRL, the ILs also slightly enhanced the enantioselectivity of the enzyme, from $E$ value of 14 (87\% ee) to $22(91 \%$ ee) with $[$ emim $]\left[\mathrm{PF}_{6}\right]$ (Table 5).

In the deprotection of acetylated thymidine 2 (Scheme 3), the regioselectivity of CAL-B or CRL was improved with all ILs tested (Table 6). The yield in monodeprotected C-5 product 5 synthesized by CAL-B was improved from 61 to $79 \%$ with the addition of $[\mathrm{bdmim}]\left[\mathrm{PF}_{6}\right]$. The yield in monodeprotected $\mathrm{C}-3$ product 6 synthesized by CRL was improved from 72 to $80 \%$ with the

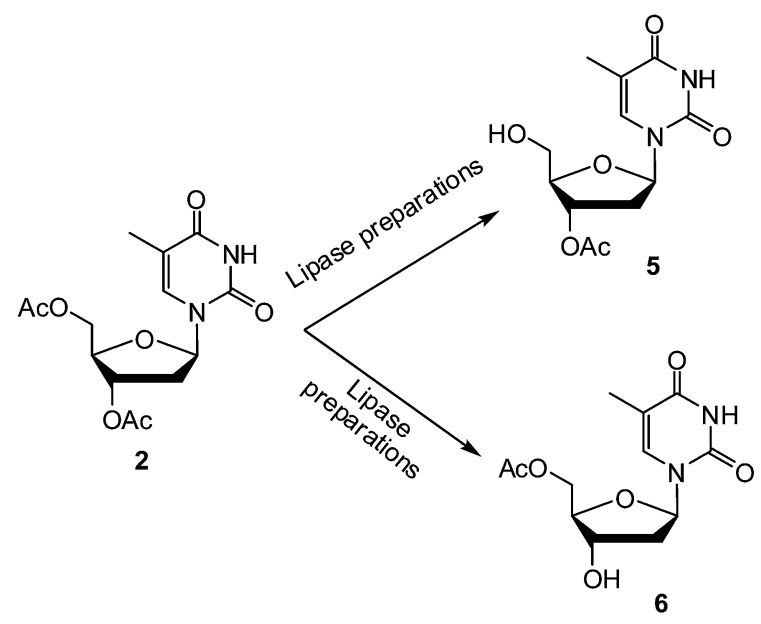

Scheme 3 Enzymatic hydrolysis of peracetylated thymidine.2. 
Table 6 Regioselective hydrolysis of 2 catalyzed by immobilized lipases in the presence of different ILS

\begin{tabular}{|c|c|c|c|c|c|c|}
\hline \multirow[b]{2}{*}{ ILs } & \multicolumn{2}{|l|}{$\mathrm{PFL}^{a, b}$} & \multicolumn{2}{|c|}{$\mathrm{CALB}^{a, c}$} & \multicolumn{2}{|l|}{$\mathrm{CRL}^{a, d}$} \\
\hline & $5^{a}(\%)$ & $6^{a}(\%)$ & $5^{a}(\%)$ & $6^{a}(\%)$ & $5^{a}(\%)$ & $6^{a}(\%)$ \\
\hline - & 28 & 51 & 61 & 3 & 10 & 72 \\
\hline$[\mathrm{emim}]\left[\mathrm{BF}_{4}\right]$ & 29 & 53 & $-f$ & $-^{f}$ & $-^{f}$ & $-^{f}$ \\
\hline$[\mathrm{emim}]\left[\mathrm{PF}_{6}\right]$ & 29 & 53 & 75 & 3 & 9 & 81 \\
\hline$[\mathrm{emim}]\left[\mathrm{NO}_{3}\right]$ & 26 & 54 & 69 & 4 & 9 & 78 \\
\hline$[\mathrm{emim}]\left[\mathrm{MeOSO}_{3}\right]$ & 26 & 54 & 73 & 1 & 9 & 76 \\
\hline$[\mathrm{bmim}]\left[\mathrm{BF}_{4}\right]$ & $15^{e}$ & $19^{e}$ & $-^{f}$ & $f$ & $f$ & $f$ \\
\hline$[\mathrm{bdmim}]\left[\mathrm{BF}_{4}\right]$ & $14^{e}$ & $19^{e}$ & $-^{f}$ & $-^{f}$ & $-^{f}$ & $-^{f}$ \\
\hline$[\mathrm{bdmim}]\left[\mathrm{PF}_{6}\right]$ & 28 & 52 & 79 & 3 & 8 & 80 \\
\hline
\end{tabular}

${ }^{a}$ Yield of the monodeprotected product at $100 \%$ conversion. The rest of yield corresponds to the bihydrolyzed product (thymidine). ${ }^{b}$ Complete reaction: $50 \mathrm{~h} .{ }^{c}$ Complete reaction: $96 \mathrm{~h} .{ }^{d}$ Complete reaction: $24 \mathrm{~h}$. ${ }^{e} 35 \%$ conversion. ${ }^{f}$ No reaction observed.

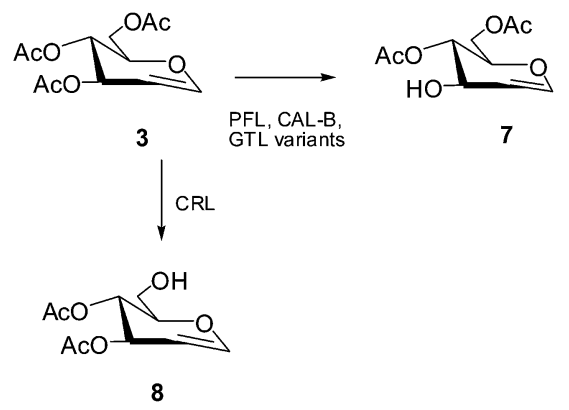

Scheme 4 Enzymatic deacetylation of 3.

addition of $[\mathrm{emim}]\left[\mathrm{PF}_{6}\right]$ or $[\mathrm{bdmim}]\left[\mathrm{PF}_{6}\right]$. The PFL regioselectivity in this process was not modified by any ILs.

In the monodeprotection of the fully acetylated glucal 3 (Scheme 4), the excellent regioselectivity of PFL, CAL-B or CRL to produce $\mathbf{7}$ or $\mathbf{8}$ respectively was conserved in the presence of the ILs (Table 7).

Under this catalytic aspect, the highest improvements on enzyme regioselectivity were observed by adding the ILs on the different GTL variants catalyzing the hydrolysis of 3 (Table 8).

The enzyme variants with the mutated unique cysteine exhibited quite interesting increase in the regioselectivity in comparison with the non mutated one, where slight changes were observed. Hence, the presence of ILs enhanced the regioselectivity of GTL $\sigma$-A193C and GTL $\sigma$-L230C variants, whereas non positive results were found for GTL $\sigma$-S196C.

The yield of 7 produced by GTL $\sigma$-A193C was increased from $74 \%$ to 87 or $89 \%$ with the addition of $[\mathrm{bmim}]\left[\mathrm{BF}_{4}\right]$ or [emim] $\left[\mathrm{PF}_{6}\right]$ respectively (Table 8 ).

However, the best regioselectivity improvement for GTL $\sigma$ L230C was achieved in the presence of [bdmim] $\left[\mathrm{PF}_{6}\right]$, from 78 to $96 \%$ yield of 7 . High yields of 7 using this variant were obtained using $[\mathrm{emim}]\left[\mathrm{PF}_{6}\right]$ or $[\mathrm{emim}]\left[\mathrm{NO}_{3}\right](92-93 \%)$ (Table 8). These results represent the first example of the regioselectivity improvement of this GTL variant in the hydrolysis of 3, which have not been achieved even with more sophisticated methodologies such as site-specific peptide modifications. ${ }^{25}$
Table 7 Regioselective hydrolysis of 3 catalyzed by immobilized commercial lipases in the presence of different ILs

\begin{tabular}{lcccc}
\hline & \multicolumn{1}{c}{ PFL } & & CALB & CRL \\
\cline { 2 - 3 } & \multicolumn{1}{c}{$7^{a}(\%)$} & & $7^{a}(\%)$ & $\mathbf{8}^{a}(\%)$ \\
\hline- & 98 & $>99$ & $>99$ \\
{$[\mathrm{emim}]\left[\mathrm{BF}_{4}\right]$} & $>99^{b}$ & $10^{c}$ & $24^{d}$ \\
{$[\mathrm{emim}]\left[\mathrm{PF}_{6}\right]$} & $>99$ & $>99$ & $>99$ \\
{$[\mathrm{emim}]\left[\mathrm{NO}_{3}\right]$} & $>99$ & $>99$ & $>99$ \\
{$[\mathrm{emim}]\left[\mathrm{MeOSO}_{3}\right]$} & $>99$ & 98 & $>99$ \\
{$[\mathrm{bmim}]\left[\mathrm{BF}_{4}\right]$} & $>99^{b}$ & $10^{c}$ & $19^{d}$ \\
{$[\mathrm{bdmim}]\left[\mathrm{BF}_{4}\right]$} & $>99^{b}$ & $10^{c}$ & $22^{d}$ \\
{$[\mathrm{bdmim}]\left[\mathrm{PF}_{6}\right]$} & $>99$ & 99 & 91
\end{tabular}

${ }^{a}$ Yield of the monodeprotected product at $100 \%$ conversion after $2 \mathrm{~h}$. The rest of yield corresponds to the bihydrolyzed product. ${ }^{b} 4 \mathrm{~h}$. ${ }^{c} 15 \%$ conversion. ${ }^{d} 27 \%$ conversion.

Table 8 Regioselective hydrolysis of 3 catalyzed by different immobilized GTL variants in the presence of different ILs

\begin{tabular}{lllll}
\hline & \multicolumn{3}{l}{$7^{a}(\%)$} & \\
\cline { 2 - 5 } ILs & GTL $\sigma$ & GTL $\sigma-A 193 C$ & GTL $\sigma-S 196 C$ & GTL $\sigma-L 230 C$ \\
\hline- & 79 & 74 & 84 & 78 \\
{$[\mathrm{emim}]\left[\mathrm{BF}_{4}\right]$} & 77 & 80 & 80 & 93 \\
{$[\mathrm{emim}]\left[\mathrm{PF}_{6}\right]$} & 87 & 89 & 85 & 88 \\
{$[\mathrm{emim}]\left[\mathrm{NO}_{3}\right]$} & 72 & 76 & 74 & 93 \\
{$[\mathrm{emim}]\left[\mathrm{MeOSO}_{3}\right]$} & 77 & 75 & 80 & 92 \\
{$[\mathrm{bmim}]\left[\mathrm{BF}_{4}\right]$} & 73 & 87 & 74 & 71 \\
{$[\mathrm{bdmim}]\left[\mathrm{BF}_{4}\right]$} & 89 & 73 & 85 & 75 \\
{$[\mathrm{bdmim}]\left[\mathrm{PF}_{6}\right]$} & 74 & 79 & 80 & 96
\end{tabular}

${ }^{a}$ Yield of the monodeprotected 3 at $100 \%$ conversion. The rest of yield corresponds to the bihydrolyzed product.

With the purpose of giving a possible explanation of the results under a structural point of view, near circular dichroism (CD) and fluorescence assays were performed in some of the most interesting examples to analyze the effect of the presence of ILs on the protein tertiary structure (Fig. 1 and 2).

First, in the case of commercial lipases, we observed how the near CD of CAL-B and PFL were altered by the presence of the ionic liquid (Fig. 1). [emim] $\left[\mathrm{BF}_{4}\right]$ caused a strong shift of the maximum peak in fluorescence for PFL, from 333 to $369 \mathrm{~nm}$, and could be related to changes in the neighboring protonated acidic groups (Asp or Glu) (Fig. 1D). Also, the CD spectrum was quite altered and this could mean changes in the aromatic amino acid residues of the protein: mobility, environment (H-bonding, polar groups and polarisability) and their spatial disposition in the protein (Fig. 1C).

Therefore these spectroscopic results and the observed decrease in the enzyme activity (nine fold) (Table 3) could suggest that the protein adopts a more closed conformation in the presence of $[\mathrm{emim}]\left[\mathrm{BF}_{4}\right]$.

The CD spectrum of CAL-B was altered in the presence of [emim $]\left[\mathrm{MeOSO}_{3}\right]$ (Fig. 1A), although the fluorescence signal did not change (Fig. 1B). In this case, the activity almost duplicated 

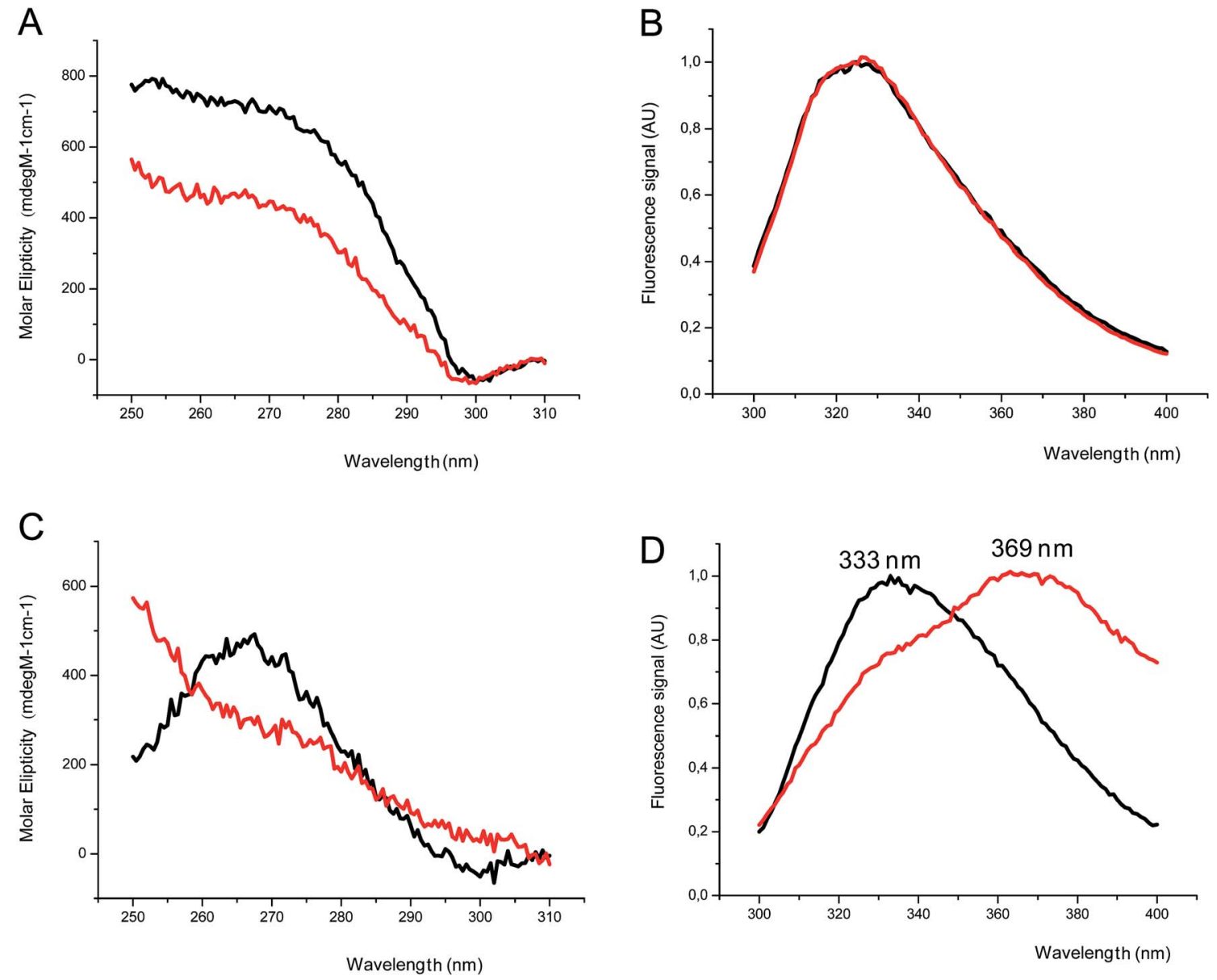

Fig. $1 \mathrm{CD}$ and fluorescence analysis of lipases in the presence of ILs in water. (A) CD spectra (near UV spectrum) of CALB (black line), CALB + [emim] $\left[\mathrm{MeOSO}_{3}\right]$ (red). (B) Fluorescence spectra of CALB and CALB + [emim][MeOSO 3$]$. (C) CD spectra (near UV spectrum) of PFL (black line), PFL $+\left[\right.$ emim] $\left[\mathrm{BF}_{4}\right]\left(\right.$ red). (D) Fluorescence spectra of $\mathrm{PFL}, \mathrm{PFL}+[\mathrm{emim}]\left[\mathrm{BF}_{4}\right]$.
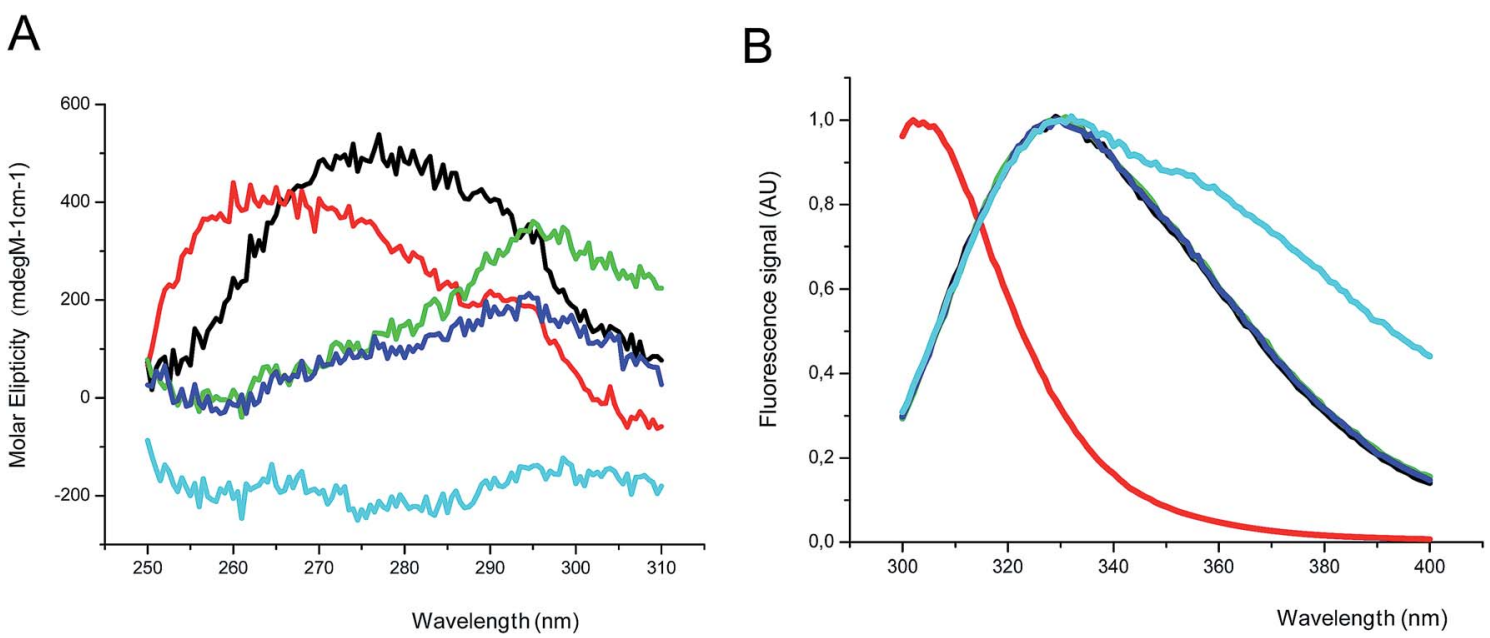

Fig. 2 CD and fluorescence analysis of GTL $\sigma$-L230C variant in the presence of ILs in water. (A) CD spectra (near UV spectrum). (B) Fluorescence spectra. GTL $\sigma-L 230 C$ (black), GTL $\sigma-L 230 C+0.1 \%$ Triton X-100 (red), GTL $\sigma-L 230 C+$ [emim] [BF 4 (light blue), GTL $\sigma-L 230 C+[b d m i m]\left[B F_{4}\right]$ (green) and GTL $\sigma-L 230 \mathrm{C}+[\mathrm{bdmim}]\left[\mathrm{PF}_{6}\right]$ (dark blue). 
its value in the presence of ionic liquid (Table 3). This suggests that the ionic liquid interacts with the protein but this interaction does not alter the open/closed protein conformation.

In the case of GTL $\sigma-\mathrm{L} 230 \mathrm{C}$ variant, the structural changes were studied in the presence of three ionic liquids, [emim] $\left[\mathrm{BF}_{4}\right]$, [bdmim $]\left[\mathrm{BF}_{4}\right]$ and $[\mathrm{bdmim}]\left[\mathrm{PF}_{6}\right]$, evaluating the effect of the IL cation and the anion (Fig. 2).

GTL $\sigma$-L230C variant CD spectra undergoes an important decrease of its signal in the presence of these three ILs, being the most remarkable the case of $[\mathrm{emim}]\left[\mathrm{BF}_{4}\right]$, followed by [bdmim $]\left[\mathrm{PF}_{6}\right]$ and then [bdmim $]\left[\mathrm{BF}_{4}\right]$ (Fig. 2A). This order is the same found in the activity data (50.1, 23.8 and 9.2 respectively) (Table 4). In addition, the best regioselectivity (93 and 96\%) were found with $[\mathrm{emim}]\left[\mathrm{BF}_{4}\right]$ and $[\mathrm{bdmim}]\left[\mathrm{PF}_{6}\right]$ respectively, ILs with the largest changes occurring in $\mathrm{CD}$ spectra. In fluorescence spectra, no significant variation was found using ILs, only the signal pick was wider for $[\mathrm{emim}]\left[\mathrm{BF}_{4}\right]$ (Fig. 2B).

These results revealed the key role of the IL cation on the structure, indicating that $[\mathrm{emim}]^{+}$is the best cation for activity improvement and $[\mathrm{bdmim}]^{+}$for the selectivity, in both cases combined with $\left[\mathrm{PF}_{6}\right]^{-}$. Thus, spectroscopic data confirm that the presence of ILs promotes conformational changes on this GTL $\sigma$-L230C variant structure that are different from those occurring in the presence of detergent (where the lid is completely opened) (Fig. 2).

In lipases, the movement of the lid is a critical point in catalysis but also involves a reorganization of the whole protein. Recently we have demonstrated how modifications on this oligopeptide create new lipase structures with new different properties. $^{25}$ Therefore, the genetic incorporation of a single cysteine in different positions of enzyme lid resulted crucial for the improvements achieved in the presence of the IL. The position of the mutation on the lid was also important. The introduction of a cysteine in residue 230 was the best option instead of 193 or 196, probably because it is surrounded by several hydrophobic residues participating together with the thiol in the interaction with the cation of the IL and in consequence shifting the movement of the lid (Fig. 3).

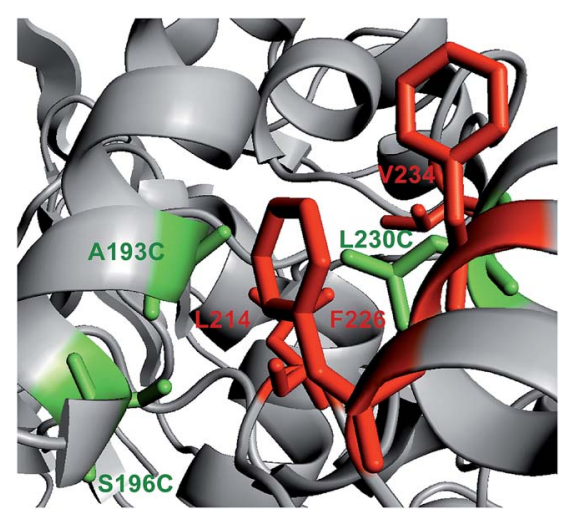

Fig. 3 Crystal structure of GTL in open conformation. The mutated positions A193, S196 and L230 are marked in green, whereas hydrophobic residues on the lid are marked in red. Figure was drawn using Pymol 0.99 program and pdb codes 2 W22.

\section{Conclusion}

Therefore, herein we present a simple and green method to improve the activity and enantio and regioselectivity of lipases in a different way. The enzyme activity of different lipases was improved from good to excellent values by the IL addition in some cases preserving the excellent enzyme selectivity and in other cases a further enhancement of the lower enantio or regioselectivity of the lipase was observed.

The addition of this very small amount of ILs in aqueous solution did not represent problems in the separation of the product, toxicity, etc., being an interesting and useful application technology for greener biocatalytic processes useful in organic and pharmaceutical chemistry.

Circular dichroism and fluorescence experiments revealed conformational changes in tertiary structure of the enzyme induced by the ionic liquid, indicating a feasible alteration of the lipase lid movement.

\section{Experimental}

\section{Materials}

The lipase from Candida antarctica (fraction B) was kindly donated by Novozymes (Denmark). Lipase from Pseudomonas fluorescens was from Amano S.A. Octyl-Sepharose (4BCL) was purchased from GE-Healthcare (Uppsala, Sweden). Lipase from Candida rugosa, ( \pm )-O-acetyl-1-phenylethanol (1), $p$-nitrophenylbutyrate ( $p$ NPB), thymidine and 3,4,6-tri- $O$-acetyl-1,5anhydro-2-deoxy-D-arabino-hex-1-enitol (3) were from SigmaAldrich. 1-Ethyl-3-methylimidazolium methyl sulphate [emim] $\left[\mathrm{MeOSO}_{3}\right]$, 1-ethyl-3-methylimidazolium nitrate $[\mathrm{emim}]\left[\mathrm{NO}_{3}\right]$, 1ethyl-3-methylimidazolium hexafluorophosphate [emim] $\left[\mathrm{PF}_{6}\right]$, 1-ethyl-3-methylimidazolium tetrafluoroborate $[\mathrm{emim}]\left[\mathrm{BF}_{4}\right], 1$ butyl-2,3-dimethylimidazolium tetrafluoroborate $[\mathrm{bdmim}]\left[\mathrm{BF}_{4}\right]$ and 1-butyl-2,3-dimethylimidazolium hexafluorophosphate [bdmim $]\left[\mathrm{PF}_{6}\right]$ were from Fluka. Peracetylated thymidine 2 was synthesized as previously described. ${ }^{25}$

\section{Enzymatic activity assay}

The activities of the soluble and immobilized lipases were analyzed spectrophotometrically measuring the increment in absorbance at $348 \mathrm{~nm}$ (isosbestic point) produced by the release of $p$-nitrophenol (pNP) $\left(\varepsilon=5150 \mathrm{M}^{-1} \mathrm{~cm}^{-1}\right)$ in the hydrolysis of $0.4 \mathrm{mM} p \mathrm{NPB}$ in $25 \mathrm{mM}$ sodium phosphate buffer at $\mathrm{pH} 7$ and $25{ }^{\circ} \mathrm{C}$. To initialize the reaction, $0.05-0.2 \mathrm{~mL}$ of lipase solution or suspension was added to $2.5 \mathrm{~mL}$ of substrate solution. Enzymatic activity is given as micromole of hydrolyzed $p$ NPB per minute per milligram of enzyme (IU) under the conditions described above.

\section{Purification and immobilization of commercial lipases on hydrophobic supports}

The enzyme was purified from crude extract by interfacial adsorption as previously described. ${ }^{26} 2.3 \mathrm{~mL}$ of commercial solution of RML (7 mg protein per $\mathrm{mL}, 25 \%$ of lipase content analyzed by Bradford's assay ${ }^{27}$ ) were added to $19 \mathrm{~mL}$ of $25 \mathrm{mM}$ 
phosphate buffer pH 7 and one gram of octyl-Sepharose was added. The reaction was maintained in stirring for $3 \mathrm{~h}$. After that, the suspension was filtered by vacuum and the solid was washed several times with distilled water.

For the others lipases, the purification/immobilization protocol was the same. In each case, it is important to calculate the right amount of crude lipase extract to add with the final objective to obtain $1 \mathrm{~g}$ of octyl-Sepharose derivative loaded with $4 \mathrm{mg}$ of pure protein. The lipase content (analyzed by Bradford's assay ${ }^{27}$ ) for each commercial crude extract was: CAL-B: 3.5 $\mathrm{mg}_{\text {protein }}$ per $\mathrm{mL}$ (100\% of lipase content); CRL: $9.5 \mathrm{mg}_{\text {protein }}$ per $\mathrm{mL}$ (100\% of lipase content); PFL: $8.8 \mathrm{mg}_{\text {protein }}$ per $\mathrm{mL}$ (100\% of lipase content).

In each case, more than $98 \%$ of the enzyme was immobilized, obtaining biocatalysts with an enzyme loading of $4 \mathrm{mg}_{\text {lipase }}$ per $\mathrm{g}$ support. SDS-PAGE analysis of the protein adsorbed to the octyl-Sepharose only showed a single band with a molecular weight corresponding to that of the different native lipases. ${ }^{26}$

The octyl-lipase immobilized preparations were used as catalysts.

\section{Site-directed mutagenesis of Geobacillus thermocatenulatus lipase (GTL)}

All site-directed mutagenesis experiments were carried out by PCR using mutagenic primers. Briefly, to introduce the amino acid change, the corresponding pair of primers was used as homologous primer pair in a PCR reaction using a specific plasmid as template and Prime Start HS Takara DNA polymerase. The product of the PCR was digested with endonuclease DpnI that exclusively restricts methylated DNA. ${ }^{28}$ E. coli $\mathrm{DH} 10 \mathrm{~B}$ cells were transformed directly with the digested product. The plasmid with mutated $g t l$ were identified by sequencing and then transformed into E. coli BL21 (DE3) cells to express the corresponding proteins. Firstly, C65S was created, and the resulting plasmid was used as template to create the double mutant C65S/C296S-GTL. ${ }^{29}$ This plasmid (pT1BGTLmutCys) was used as template to construct additional mutations (A193C, S196C, L230C) using different mutagenic primers: A193C (Ala/cys 193-5,5'-GAAAGCGtgcGCTGTCGCCAG; Ala/cys 193-3 5'-CTGGCGACAGCg caCGCTTTC), S196C (Ser/ Cys196-5 5'-GTTGAAAGCGGCG GCTGTCGCCtgcAA TGTGCCGTA CACGAGTCAAG'Ser/Cys196-3,5'-CTTGACTCGTGTACGGCA CATT gcaGGCGACGCCGCCGCTTTCAAC) and L230C (Leu/Cys 230-5 5'CATTATTTTGAACGGtgcAAACG, Leu/Cys 230-3 5'-CGTTTgcaCCG TTCAAAA TAATG).

\section{Cloning, expression, purification and immobilization of GTL variants}

The gene corresponding to the mature lipase from G. thermocatenulatus (GTL) was cloned into pT1 expression vector as previously described. ${ }^{28}$ Cells carrying the recombinant plasmid pT1GTL were grown at $30{ }^{\circ} \mathrm{C}$ and over expression were induced by raising the temperature to $42{ }^{\circ} \mathrm{C}$ for $20 \mathrm{~h}$. The enzyme was purified from $E$. coli crude extract by interfacial adsorption on butyl-Sepharose as previously described..$^{30}$ The lipase was desorbed from the support adding $20 \mathrm{~mL}$ of $25 \mathrm{mM}$ phosphate buffer pH 7 with $0.5 \%$ Triton X-100 (v/v) per gram of support. After that, the detergent was removed by ultracentrifugation and the lipase variants were immobilized on octyl-Sepharose at $\mathrm{pH} 7$ in $25 \mathrm{mM}$ sodium phosphate buffer for $1 \mathrm{~h}$ at $25^{\circ} \mathrm{C}(>95 \%$ immobilization yields) with a final loading of $5 \mathrm{mg}_{\text {lip }} \mathrm{g}_{\text {cat }}{ }^{-1} .^{30}$ The remaining pNPB activity for the different immobilized GTL variants was more than $95 \%$ of the initial activity.

\section{Enzymatic biotransformations}

$2 \mathrm{mM}$ of 1-3 in $25 \mathrm{mM} \mathrm{NaH}{ }_{2} \mathrm{PO}_{4} 98 \% / \mathrm{CH}_{3} \mathrm{CN} 2 \%$ and 5 eq. of ionic liquid at pH 5 and $25{ }^{\circ} \mathrm{C}$ were prepared. $0.4 \mathrm{~g}$ of immobilized lipase were added to $2 \mathrm{~mL}$ of the previous solution to initialize the reaction. The hydrolytic reaction was carried out under mechanical stirring and the $\mathrm{pH}$ value was controlled by automatic titration. Hydrolysis reactions were followed by HPLC using a HPLC spectrum P100 (Thermo Separation products). At least triplicates of each assay were made.

The HPLC analysis was performed using a Kromasil- $\mathrm{C}_{18}(250$ $\times 4.6 \mathrm{~mm}$ and $5 \mu \mathrm{m} ø$ ) column. Analyses were run at $25^{\circ} \mathrm{C}$ using an L-7300 column oven couple to a UV detector L-7400. For substrate 1 and 3, the hydrolytic conversion was determined at $215 \mathrm{~nm}$ and the mobile phase was an isocratic mixture of $25 \%$ acetonitrile/75\% $10 \mathrm{mM}$ ammonium phosphate buffer at $\mathrm{pH}$ 3.8; flow rate $1.0 \mathrm{~mL} \mathrm{~min}^{-1}$. Under these conditions, the retention times were: $3=30 \mathrm{~min}, 7=6.8 \mathrm{~min}$ and $8=7.3 \mathrm{~min}$.

The enantiomeric excess of product $S \mathbf{- 4}$ was determined by chiral reverse-phase HPLC, using pure commercial enantiomers as standards. The column was chiracel OD-R and the mobile phase was an isocratic mixture of $35 \%$ acetonitrile and $65 \% 10$ $\mathrm{mM}$ sodium phosphate buffer at $\mathrm{pH}$ 7. The analyses were performed at fixed flow of $0.45 \mathrm{~mL} \mathrm{~min}^{-1}$ by recording the absorbance at $225 \mathrm{~nm}$.

For substrate 2 , the hydrolytic conversion was determined at $260 \mathrm{~nm}$ and the mobile phase was a gradient mixture of A: 10 $\mathrm{mM} \mathrm{NH} \mathrm{H}_{2} \mathrm{PO}_{4} 90 \% / \mathrm{CH}_{3} \mathrm{CN} 10 \% \mathrm{pH} 4.2 ; \mathrm{B}: \mathrm{CH}_{3} \mathrm{CN} 90 \% / \mathrm{H}_{2} \mathrm{O}$ 10\%; method: $0-6 \min 100 \% \mathrm{~A}$; 6-14 min $65 \% \mathrm{~A}$ and $35 \% \mathrm{~B}$; 14-22 $\mathrm{min} 100 \% \mathrm{~A}$; flow rate $1.0 \mathrm{~mL} \mathrm{~min}^{-1}$. Under these conditions, the retention times were: $2=13.3 \mathrm{~min}, \mathbf{5}=8.4 \mathrm{~min}$, $6=7.6 \mathrm{~min}$ and thymidine $=2.1 \mathrm{~min}^{.24}$

\section{Product characterization}

$\mathbf{5}^{\prime}$-O-Acetylthymidine (5). This compound was characterized how previously reported in literature. ${ }^{24}$

3'-O-Acetylthymidine (6). This compound was characterized how previously reported in literature. ${ }^{24}$

4,6-Di-O-acetyl-D-glucal (7). ${ }^{1} \mathrm{H}-\mathrm{NMR}\left(500 \mathrm{MHz}, \mathrm{CDCl}_{3}\right) \delta$ : $6.35(\mathrm{dd}, J=6.2 \mathrm{~Hz}, 1 \mathrm{H}, \mathrm{H}-1), 4.95$ (dd, $J=8.4,6.2 \mathrm{~Hz}, 1 \mathrm{H}, \mathrm{H}-4)$, 5.41-5.50 (m, 1H, H-3), 4.84 (dd, $J=6.2,5.2,3 \mathrm{~Hz}, 1 \mathrm{H}, \mathrm{H}-2), 4.27$ (dd, $J=12.9,6.2 \mathrm{~Hz}, 1 \mathrm{H}, \mathrm{H}-3), 4.11$ (ddd, $J=3.1 \mathrm{~Hz}, 1 \mathrm{H}, \mathrm{H}-5$ ), 4.20-4.37 (m, 2H, H-6A, H-6B), 2.55 (bs, 1H, OH), 2.16 (s, 3H, $\left.\mathrm{CH}_{3}\right), 2.11\left(\mathrm{~s}, 3 \mathrm{H}, \mathrm{CH}_{3}\right)$.

3,4-Di-O-acetyl-D-glucal (8). ${ }^{1} \mathrm{H}-\mathrm{NMR}\left(500 \mathrm{MHz}, \mathrm{CDCl}_{3}\right) \delta$ : 6.49 (dd, $J=6.1 \mathrm{~Hz}, 1 \mathrm{H}, \mathrm{H}-1), 5.41-5.50$ (m, 1H, H-3), 5.22 (dd, $J=9.0,6.5 \mathrm{~Hz}, 1 \mathrm{H}, \mathrm{H}-4), 4.81$ (dd, $J=5.9,2.8 \mathrm{~Hz}, 1 \mathrm{H}, \mathrm{H}-2), 3.98-$ 4.09 (m, 1H, H-5), 3.66-3.86 (m, 2H, H-6A, H-6B), 2.07-2.13 (2s, $\left.6 \mathrm{H}, 2 \mathrm{CH}_{3}\right)$. 


\section{Circular dichroism}

Circular dichroism (CD) spectra of the different lipases with or without ILs were recorded in a Chirascan spectropolarimeter (Applied Photophysics) at $25( \pm 1){ }^{\circ} \mathrm{C}$. Near-UV spectra were recorded at wavelengths between 250 and $310 \mathrm{~nm}$ in a $1 \mathrm{~cm}$ path-length cuvette, with $10 \mu \mathrm{M}$ protein solutions in phosphate buffered saline, pH 7.2 (PBS; bioMerieux).

\section{Fluorescence spectroscopy}

Fluorescence measurements were performed in a Varian Cary Eclipse Fluorescence Spectrophotometer (Agilent Technologies) monitoring the intrinsic tryptophan fluorescence in the different GTL variants, using an excitation wavelength of 280 $\mathrm{nm}$, with excitation and emission bandwidths of $5 \mathrm{~nm}$, and recording fluorescence emission spectra between 300 and 400 $\mathrm{nm}$. All spectroscopic measurements were made in water.

\section{Acknowledgements}

This work has been sponsored by CSIC and the Spanish Ministry of Economy and Competitiveness (Project EUIN201351161). The authors also thank to Dr Ramiro Martinez from Novozymes for the generous gift of lipases.

\section{Notes and references}

1 E. Siirola, A. Frank, G. Grogan and W. Kroutil, Adv. Synth. Catal., 2013, 355, 1677.

2 J. Brabcova, M. Filice, M. Gutarra and J. M. Palomo, Curr. Bioact. Compd., 2013, 9, 113.

3 T. Hudlicky and J. W. Reed, Chem. Soc. Rev., 2009, 38, 3117.

4 M. T. Reetz, J. Am. Chem. Soc., 2013, 135, 12480.

5 E. Busto, V. Gotor-Fernández and V. Gotor, Chem. Soc. Rev., 2010, 39, 4504.

6 A. M. Brzozowski, U. Derewenda, Z. S. Derewenda, G. G. Dodson, D. M. Lawson, J. P. Turkenburg, T. Bjorkling, B. Huge-Jensen, S. S. Patkar and L. Thim, Nature, 1991, 351, 491.

7 L. Sarda and P. Desnuelle, Biochim. Biophys. Acta, 1958, 30, 513.

8 J. M. Palomo, M. Fuentes, G. Fernández-Lorente, C. Mateo, J. M. Guisan and R. Fernández-Lafuente, Biomacromolecules, 2003, 4, 1.

9 J. M. Palomo, Curr. Org. Synth., 2009, 6, 1.
10 M. Marciello, M. Filice and J. M. Palomo, Catal. Sci. Technol., 2012, 2, 1531.

11 C. A. Godoy, B. de las Rivas, M. Filice, G. Fernandez-Lorente, J. M. Guisan and J. M. Palomo, Process Biochem., 2010, 45, 534.

12 M. L. E. Gutarra, O. Romero, O. Abian, F. A. G. Torres, D. M. G. Freire, A. M. Castro, J. M. Guisan and J. M. Palomo, ChemCatChem, 2011, 3, 1902.

13 Z. Yang and Z.-L. Huang, Catal. Sci. Technol., 2012, 2, 1767. 14 P. Dominguez de Maria, Angew. Chem., Int. Ed., 2008, 47, 6960.

15 M. Sandoval, A. Cortes, C. Civera, J. Trevino, E. Ferreras, M. Vaultier, J. Berenguer, P. Lozano and M. J. Hernaiz, RSC Adv., 2012, 2, 6306.

16 A. Shariati, R. A. Sheldon, G.-J. Witkamp and C. J. Peters, Green Chem., 2008, 10, 350.

17 F. Van Rantwijk and R. A. Sheldon, Chem. Rev., 2007, 107, 2757.

18 R. A. Sheldon, Chem. Commun., 2008, 3352.

19 Z. Yang, J. Biotechnol., 2009, 144, 12.

20 M. Klähn, G. S. Lim and P. Wu, Phys. Chem. Chem. Phys., 2011, 13, 18647.

21 S. P. M. Ventura, L. D. F. Santos, J. A. Saraiva and J. A. P. Coutinho, Green Chem., 2012, 14, 1620.

22 M. Filice, J. M. Guisan and J. M. Palomo, Green Chem., 2010, $12,1365$.

23 A. S. Rowan and C. J. Hamilton, Nat. Prod. Rep., 2006, 23, 412.

24 T. Bavaro, S. Rocchietti, D. Ubiali, M. Filice, M. Terreni and M. Pregnolato, Eur. J. Org. Chem., 2009, 12, 1967.

25 O. Romero, M. Filice, B. de las Rivas, C. Carrasco-Lopez, J. Klett, A. Morreale, J. A. Hermoso, J. M. Guisan, O. Abian and J. M. Palomo, Chem. Commun., 2012, 72, 9053.

26 J. M. Palomo, G. Muñoz, G. Fernández-Lorente, C. Mateo, R. Fernandez-Lafuente and J. M. Guisan, J. Mol. Catal. B: Enzym., 2002, 19-20, 279-286.

27 M. M. Bradford, Anal. Biochem., 1976, 72, 248-254.

28 C. Schmidt-Dannert, M. L. Rua, H. Atomi and R. D. Schmid, Biochim. Biophys. Acta, 1996, 1301, 105.

29 C. A. Godoy, B. de las Rivas, V. Grazú, T. Montes, J. M. Guisán and F. López-Gallego, Biomacromolecules, 2011, 12, 1800.

30 G. Fernández-Lorente, C. Godoy, A. A. Mendes, F. LopezGallego, V. Grazu, B. de las Rivas, J. M. Palomo, J. A. Hermoso, R. Fernandez-Lafuente and J. M. Guisan, Biomacromolecules, 2008, 9, 2553. 